\title{
Die Groot Trek en die Kerk
}

\author{
AD Pont \\ Universiteit van Pretoria
}

\begin{abstract}
The Great Trek and the Church
\end{abstract}

The emigration of about 15000 pioneer-farmers from the eastern Cape districts to the interior of Southern Africa, was a definite turning point in South African history. In 1852-1854, which can be regarded as the final date of the Great Trek, there were in South Africa two British colonies $i$ e the Cape and Natal and two Boer republics $i$ e the Transvaal and the Orange Free State. This study traces the history of the church during the emigration and the establishment of the church by the emigrants.

\section{INLEIDEND}

Die Groot Trek, die emigrasie van ongeveer 15000 Hollands-Afrikaanssprekende pioniers uit die oosgrensdistrikte van die Kaapkolonie in die jare 1835 tot ongeveer 1838, het die geskiedenis van die Afrikaner beslissend bepaal (Duvenage 1986: 11). Nie alleen is die leë en verlate binnelande van Suidelike Afrika beset nie, maar terselfdertyd is die politieke, kulturele en lewensbeskoulike botsing tussen die Engels-imperialistiese wereld en die Afrikaner-denke uitgebrei en oorgedra na die toekoms. Terselfdertyd is sommige van die swart volkere van Suidelike Afrika se geskiedenis ook beslissend deur die Groot Trek bepaal.

As die Groot Trek min of meer afgesluit word deur die Sandrivierkonvensie van 1852 en dié van Bloemfontein in 1854, en 'n soort rekening opgemaak kan word dan bestaan daar in die binneland, naas die Kaapkolonie, 'n tweede Engelse kolonie in Natal en wes van die Drakensberge, die twee Boere-republieke in die Oorvaalse en in die gebied tussen die Oranje- en die Vaalrivier. So word die grenslyne getrek vir die daaropvolgende stryd wanneer die Engelse imperialisme, aangepor deur die Londense geldbase, ook die gebied noord van die Oranje wil hê (Quigley 1974: 134138).

Met die totstandkoming van die ou Zuid-Afrikaansche Republiek op die basis 
van die Sandrivierkonvensie, word die Groot Trek-ideale duidelik vorm gegee in 'n omlynde staatkundige bestel. Dit bring ook ' $n$ organisatoriese kerklike verdeeldheid tot stand, want in Augustus 1853 het die Algemene Kerkvergadering van die latere staatskerk in die ZAR verklaar: '... burgerlijk vrij en onafhankelijk, wenschen wij dit ook in het kerkelijke' (Gerdener 1930: 208).

Dárdie beslissing was alleen moontlik in die lig van die voorafgaande geskiedenis want die Voortrekkers, as op hulle doelwitte gelet word (Duvenage 1986: 12 13), was nie fortuinsoekers nie. Hulle wou 'n eie vaderland soek om daar 'n eie gemeenskapslewe, ingerig volgens hulle opvattings, te vestig. Daardie gemeenskapslewe het vanselfsprekend die instandhouding van die kerk ingesluit. Uiteindelik beteken dit die oprigting van 'n kerklike struktuur en dit kry gestalte in die staatskerk. Maar, en dit is in die Voortrekkergemeenskap miskien nie so vreemd nie, die staatskerk was toe uiteindelik nie die enigste kerklike struktuur wat die Voortrekkers opgerig het nie.

Dié ontwikkeling word nou kortliks nagegaan.

\section{DIE VOORTREKKERS AS LIDMATE VAN DIE KERK}

In die kolonie waar die ortodoks-Calvinistiese opvatting van 'n gereformeerde kerkstaat gegeld het, soos dit in 1651 in Nederland geproklameer is (Pont 1986: 36), was daar vir die tydperk tot 1804 vanselfsprekend net én kerk in die kolonie. Daarin kom verandering vanweë De Mist se reëlings in 1804 (Dreyer 1936: 8-23), terwyl die permanente Engelse oorname van die kolonie na 1806, Engelssprekende kerke in die kolonie gebring het (Mears 1973: 5). Tog was daar in die oosgrensdistrikte net die een kerk waaraan al die inwoners feitlik vanselfsprekend behoort het. Dit was die kerk wat deur Van Riebeeck as ' $t$ ware saamgebring is na Suid-Afrika en wat homself in 1824 amptelik De Nederduitsche Hervormde Kerk in Zuid-Afrika genoem het (Dreyer 1936: $212 \mathrm{vv}$ ).

Dit is nié so maklik om vandag nog 'n duidelike beeld te vorm van die teologiesgodsdienstige klimaat wat in die oosgrensgemeentes, waarvandaan die Voortrekkers gekom het, geheers het nie. Oor die algemeen word aanvaar dat die lidmate meerendeels aanhangers was van die Nederlandse Nadere Reformasie-beweging (Malan 1981: 44-45). Dié beweging wat gestimuleer is deur die invloed van Helperus Ritzema van Lier (1764-1793) (Hanekom 1959: 313) en MC Vos (1775-1825) is volgens Du Toit (1972: 844) reeds deur die sieketroosters in die vroeë Kompanjiestyd aan die Kaap gevestig. Vandaar het dit feitlik dwarsoor die Kaap uitgebrei, maar waar dit in die omstreke van Kaapstad en Stellenbosch deur ander teologiese opvattings vervang is (Spoelstra 1963: $33 \mathrm{vv}$ ), het dit vanweë die invloed van die oude schrijvers, die bepalende opvatting aan die oosgrens gebly. 
Dit het beteken dat die Voortrekkers se godsdienstige opvattings grotendeels bepaal is deur die Staten-ijbel met sy Calvinisties-bepaalde kanttekeninge (Canisius 1986: 61), die Psalm- en Gesangboek, die Heidelbergse Kategismus en die werke van die oude schrijvers of outeurs (De Klerk 1918: 256). Onder die oude schrijvers het A Hellenbroek se Kort Begrip der Christelijke religie getel asook preekbundels van B Smijtegeld, W Sluyter, Jodocus Lodenstein en A Comrie, asook W á Brakel se populêre dogmatiek, Redelijke godtsdienst, gebedeboeke en derglike meer.

As die Nadere Reformasie op grond van hierdie en ander geskrifte bepaal moet word, dan kan gestel word dat dit op die basis van die Calvinistiese ortodoksie gebou was. Dié ortodoksie wat in die sewentiende eeu al meer 'n skolastieke tendens, vanweë sy uitgangspunt in die leer van die uitverkiesing gekoppel aan die Godsleer (Pont 1988: 404 vv), ontwikkel het, het die reaksie-verskynsel van die Nadere Reformasie opgeroep. Daarin is 'n onderskeid tussen leer en lewe gemaak en is die klem op die vrome lewenswandel geplaas (Van't Spijker 1986: 7).

Tog handhaaf die Nadere Reformasie nog die teokratiese ideaal van die Calvinistiese ortodoksie waardeur die hele lewe en alle lewensvorme onder die gesag van God en sy Woord geplaas is. Dit verklaar ook waarom die Voortrekkers hulleself as verbondsvolk gesien het, want deur die doop is hulle in 'n bepaalde verhouding tot God geplaas met die opdrag om Hom in alles diensbaar te wees (Graafland 1986: 365-366). Juis omdat hulle hulleself so as verbondsvolk waardeer het, het hulle ' $n$ ooreenkoms tussen hulleself en die ou verbondsvolk, Israel, gesien (Van Genderen 1986: 171). In hulle heilshistoriese verstaan van die Ou Testament, wat 'n kenmerk van die Calvinistiese ortodoksie was, het hulle dikwels die Ou Testament analogies verstaan en uitgelê sonder dat dit hulle 'Ou-Testamentiese gelowiges' gemaak het of dat hulle hulleself as ' $n$ 'uitverkore volk' (Van Jaarsveld 1974: 97) verstaan het. As verbondsvolk was hulle egter deeglik bewus van hulle roeping en opdrag om God in alles te dien en te eer (Spoelstra 1963: 23-24). Juis die besef het die klem op die vrome lewenswandel verswaar en die besef gekweek dat alles in die hand van God le. Vandaar dat hulle lewensritme so duidelik deur hulle godsdiens bepaal is, deur die reëlmatige oggend- en aandhuisgodsdiens en die Sondagse godsdiensoefening in die familiekring waar 'n preek van een van die oude schrijvers gelees is. Op Sondagmiddae is die kinders deur die huisvader gekatkiseer (Du Plessis 1898: 311). So was die Voortrekkers die draers van 'n deurleefde godsdiens.

Die klem wat die Nadere Reformasie geplaas het op elke gelowige as 'n verantwoordelike lid van die Godsvolk, het 'n godsdienstige selfstandigheid ontwikkel wat ingepas het by die pioniersomstandighede waarin die Voortrekkers geleef het waar hulle, feitlik in alles, selfversorgend moes wees. Dit is tiperend van die Voortrekkers dat in die nagelate uitsprake en briewe van leiers soos Piet Retief, Hendrik 
Potgieter, Andries Pretorius en andere, godsdienstig-teologiese argumente gevind word. Daaruit blyk nie alleen hulle vaste geloof en godsdienssin nie, maar ook 'n merkwaardige vertroudheid met die Heilige Skrif.

Die Voortrekkers se kerklike betrokkenheid was vanweë die uitgestrektheid van die gemeentes en die kwaliteit van die vervoermiddels grotendeels beperk tot Nagmaalsvierings. Dit het beteken dat hulle betreklik min in aanraking gekom het met die Skotse predikante wat in die oosgrensgemeentes gestaan het (Gerdener 1934: 5). Tog is Gerdener (1934: 6) van mening dat daar wel 'n mate van spanning tussen die Skotse predikante en hulle lidmate was omdat die Skotte die ideale en strewes van hulle lidmate nie werklik kon peil nie.

\section{DIE KERK EN DIE GROOT TREK}

Die reaksie van die Kaapse kerk op die Groot Trek het duidelik aangetoon dat die oorsake en motiewe vir die landverhuising in die breë kerklike kring nie verstaan of waardeer is nie. Die grootste enkele oorsaak lê waarskynlik dáárin dat die kerk in die Kolonie feitlik as 'n staatskerk gefunksioneer het en dat die predikante omtrent staatsamptenare was (Kleynhans 1973: $54 \mathrm{vv}$ ). Dit het beteken dat veral die predikante nie die politiek-lewensbeskoulik-kulturele botsings tussen die Kaapse owerheidsbeleid en die Voortrekkers raakgesien of verstaan het nie (Duvenage 1986: 613). Die probleem is as ' $t$ ware vererger deur die feit dat in die oosgrensgemeentes net Skotte as predikante gestaan het. Hulle het, byna vanselfsprekend nie veel begryp van hulle lidmate se probleme met die owerheid en sy beleid nie. Daarom was dit vir hulle ook nie moeilik om gehoor te gee aan die oproep van die Kaapse goewerneur dat hulle hulle invloed moet gebruik om die massa-uittog te probeer keer nie (Gerdener 1934: 12-18). Die afstand tussen die predikante en hulle lidmate word effektief geillustreer deur die publikasie van 'n Herderlijke Brief in opdrag van die sinode van 1837 waarin die emigrasie skerp veroordeel is (Pont 1978: 97). Faktore wat die Brief moontlik gemaak het, was die owerheidsproklamasie van 11 September 1834 wat trekbewegings oor die grense verbied het (Duvenage 1986: 18), en daarby Artikel 7 van die Algemeen Reglement van 1824.

Die sinode het nie alleen 'n negatiewe oordeel oor die Trek uigespreek nie, maar in beginsel die Voortrekkers se lidmaatskap vervalle verklaar. Die sinode het gestel dat deur weg te trek, die Voortrekkers:

- die verpligting van die doopbeloftes ontduik;

- die beloftes afgelê by die openbare geloofsbelydenis, nie meer nakom nie;

- teen die wil van God handel;

- in verset is teen die owerheid, en 
- nie genoeg vertroue in Haar Britse Majesteit Victoria het nie.

Die sinode se stilswyende veronderstelling was dat die Voortrekkers in hulle optrede sal volhard. Daarom word die gronde uiteengesit om aan te toon dat die Voortrekkers eintlik onder kerklike sensuur geplaas en uiteindelik met die ban afgesny moes word. Meer kon die sinode nie doen nie, omdat die Voortrekkers die fisiese grense van die kerk oorgesteek het en dus buite die jurisdiksie van die kerk gestaan het.

Die toepassing van die riglyne wat die Herderlijke Brief neergelê het, is in die hande van die ring- en kerkraadsvergaderings gelaat. In 1838 het ds Thomas Reid van Colesberg dié saak op die ringsvergadering van Graaff-Reinet aan die orde gestel (Dreyer 1929: 27-29). Die ringsvergadering het, op voorstel van die ringsvoorsitter, ds Andrew Murray snr, besluit:

Dat de Ringsvergadering zich bezwaard voelt wegens de bijzondere en ongehoorde omstandigheden waarin de bewoners van de gewesten aan de Noorde zijde der Oranje rivier en buiten de grenzen der volksplanting gelegen, zich bevinden om een algemeene regel voor te schrijven, waarnaar men behoort te handelen in ieder geval 't welk zoude kunnen gebeuren, maar dat de Vergadering ieder Kerkeraad recommandeert om in elk bijzonder geval van dien aard waarop bedoelt wordt, te handelen zoveel als mogelijk met de grootste voorzigtigheid en tevens met Christelijke toegevendheid, overeenkomstig met de bestaande wetten en gebruiken der Kerk.

Volgens Van der Watt (1973: 13) het die ietwat vae besluit beteken dat kerklike voorregte geweier moet word aan Voortrekkers wat daarvoor na die Kolonie terugkeer. In 1840 het dieselfde ring ds Reid belet om sakramente te bedien aan mense wat buite die Kolonie langs die Riet-, Sand- en Kafferrivier woon (Dreyer 1929: 29). De Jongh (1981: 215) wys daarop dat veldkornet Gideon Joubert oortuig daarvan was dat die emigrante wat oor die Oranjerivier sou trek met eens van ons kerk afgesneden is. Aan die ander kant toon Dreyer (1929: 32) ook aan dat hoewel ds Taylor deur die Ring van Graaf-Reinet verbied is om die sakramente op besoeke na die Voortrekkers te bedien, hy tog van tyd tot tyd van hulle kinders gedoop het. Die besluit van die Herderlijke Brief het dus 'n duidelike gevolg gehad en wel dat die Ring van Graaff-Reinet dit so verstaan dat die Voortrekkers nie meer lidmaatvoorregte in die kerk gehad het nie. Dié besluit is egter nie konsekwent uitgevoer nie, maar dit kan gestel word dat die Herderlijke Brief en die daaropvolgende 
optrede van die ring van Graaff-Reinet 'n duidelike afstand tussen die kerk in die Kolonie en die Voortrekkers afgebaken het. Vobr, tydens en na die Herderlijke Brief het buitendien die meerderheid van Kaapse predikante die Groot Trek afgewys of veroordeel en probeer om hulle lidmate van dié 'dwaasheid' (Dreyer 1929:6) te laat afsien (Spoelstra 1963: 101).

Uitsonderings was daar ook, en wel ds GWA van der Lingen wat nog deur Andries Pretorius as een waare Afrekaan aangedui is (Dreyer 1919: 14) en ds J le F Moorrees, maar hulle was ' $n$ minderheid. Bo en behalwe die houding wat die vergadering van ampsdraers van die kerk ingeneem het, het die Herderlijke Brief en die posisie van die predikante in die kerk beteken dat die Voortrekkers se pogings om 'n predikant te kry om hulle te vergesel, nie kon slaag nie. In die eerste plek omdat die beroepstelsel vir predikante op daardie stadium nie in die Kapse kerk bestaan het nie, omdat die Goewerneur die eksklusiewe reg gehad het om die predikante wat deur die owerheid besoldig is, te plaas en te verplaas, en tweedens omdat 'n predikant wat met die Groot Trek sou saamgegaan het, homself van die kerk sou afgesny het, danksy die Herderlijke Brief van 1837 (Spoelstra 1963: 102-103). Dié afwysende houding van die predikante is seker vir 'n groot deel bepaal deur die standpunt van die Engelse owerheid aan die Kaap wat, tot en met die Sandrivierkonvensie, die Voortrekkers as opstandige Britse burgers beskou het wat nié van hulle lojaliteit teenoor die Britse kroon ontslaan is deur die feit dat hulle die kolonie verlaat het nie (Pont 1987: 158-164).

Daarom was dit ook so, dat alleen nádat die Engelse owerhede hulle met die Trekkers begin bemoei het, Kaapse predikante die Voortrekkers besoek het. Die eerste Kaapse predikant wat so by die Voortrekkers uitkom, was dr Abraham Faure wat na die anneksasie van Natal in 1843 op koste van die Goewerneur soontoe gestuur is om die Voortrekkers te paai (Spoelstra 1963: 103).

Die Trans-Oranje word eers in 1846 deur ds WA Krige namens die Ring van Graaff-Reinet besoek maar hy ondervind naas aanvaarding ook weerstande onder die Voortrekkers (Dreyer 1929: 84 vv). In 1847 het die Kaapse sinode 'n driemankommissie bestaande uit ds A Murray, ds PK Albertyn en oudl B Pienaar na die Voortrekkers gestuur. Hulle besoek die Trans-Oranje, kort nadat die deel van die Voortrekkerrepubliek deur sir Harry Smith geannekseer is, en daarvandaan ook die Oorvaalse gebied. Die anneksasie en die daaropvolgende argwaan teen die Engelse owerheid in die Kaap het meegebring dat hulle besoek nie werklik kerklike bande kon smee nie (Engelbrecht 1955: 59-60). 'n Verdere kommissie bestaande uit ds PE Faure en dr WM Robertson, bekend vanweë sy smalende opmerkings oor die Groot Trek (Engelbrecht 1955: 60), is na die slag van Boomplaas na die Oranjerivier Soewereiniteit gestuur. Dié kommissie se werksaamhede is ook gedwarsboom 
deur die noue verbondenheid van die Kaapse kerk met die Engelse owerheid en die feit dat die kommissielede nie anders kon as om die Engelse politieke doelwitte te bevorder nie (Gerdener 1930: 101, 105). Nogal tiperend van die situasie was die opmerking van dr PE Faure aan Andries Pretorius in 'n skrywe van 1 Maart 1849. Daar stel hy dat verdere stryd teen Engeland rampspoedig vir die Oorvaalse sal wees, want dit sal lei tot ... verlies van dierbare levens en nog verdere verwydering van de oude Kolonie én van onze dierbare Kerk... (Gerdener 1930: 545). Interessant is dat Pretorius op dié opmerking gereageer het deur terug te skrywe (Pretorius \& Kruger 1937: 365):

...wy weeten dat het Gouvernement van Engeland sterker van magt zyn dan wy, maar wy weeten ook teefens, de magt des Heere sterker zyn dan wy alle, en ook weet wy dat Engeland ook zyn struikelblokken heeft gelyk wy. Doch wanneer onze magt na evenredigheit is, zoude de Heere geen loft genoeg hebbe, maar ziet terug op Gideon, ....

Die verknooptheid van die Kaapse kerk met die Engelse owerheid in die kolonie het inderdaad ' $n$ verwydering en ' $n$ afstand met die Voortrekkers bestendig wat vanaf die begin van die emigrasie bestaan het. Hoewel daar onder die Voortrekkers wel waardering was vir sommige besoekende predikante en hulle dienswerk, was daar ook afkeer van predikante wat deur die Britse owerheid betaal is (Spoelstra 1963: 105).

\section{DIE VOORTREKKERKERK}

Die Voortrekkers het na hulle vertrek uit die Kaapkolonie ook op kerklike terrein nié passief afgewag wat moet gebeur nie. Die teendeel is eerder waar. Omdat dit van die begin af die Voortrekkers se ideaal was om 'n nuwe vaderland te soek waar die volkslewe onder ' $n$ eie regering in vryheid kon groei en gedy (Duvenage 1986: 13), het hulle feitlik onmiddellik aandag gegee aan die skepping van samelewingstrukture. Omdat hulle verder 'n homogene gemeenskap was, ondanks onderlinge verskille, was dit vanweë hulle Calvinisties bepaalde teokratiese ideaal vanselfsprekend dat hulle ook die kerklike samelewing as keersy van die burgerlike samelewing moes orden. Die eerste poging tot ordening was die bestuursreëling wat op 2 Desember 1836 deur die Maritz-en Potgietertrekke aanvaar is (Storm 1984: 41-42). Dié reëling word vervang op 17 April 1837 wanneer die grondreëls vir die Vereenigde Maatschappij aanvaar word en Retief as goewerneur gekies word. Op $21 \mathrm{Mei}$ 1837 word Erasmus Smit deur die Goewerneur as predikant aangestel en in sy amp bevestig as leeraar voor onze Reizende Gereformeerde Kerkgemeente in de Woestyn 
(Schoon 1897: 22).

Dat diê reëlings nie buite orde was nie, word bevestig deur á Brakel wat stel dat in 'n noodgeval heeft de Kerke, ... macht om eenige uyt haer die bequaem zyn, tot dat groote werk te roepen .... (a Brakel 1736: 640). So het Erasmus Smit op 'n aanvaarbare wyse die eerste bevestigde predikant van die Voortrekkerkerk geword.

Hoewel Erasmus Smit self nooit meer as 'n kort sendelingopleiding ontvang het nie (De Jongh 1977: 14) was hy, gesien sy optrede en die standpunte wat hy in sy Dagboek stel, nie onbedrewe in die teologie nie en is dit maklik om sy vermoenns op hierdie vlak te onderskat.

Daarna is by Kerkenberg weer 'n voltallige kerkraad gekies en op 3 Desember 1837 in hulle ampte bevestig (Schoon 1897: 49). So is deur die optrede van Retief, kragtens die ius patronatus van die owerheid, soos dit ook in die Kolonie gegeld het, orde in die kerklike samelewing gebring en die grondslae van 'n onafhanklike Voortrekkerkerk in die onafhanklike Voortrekkergemeenskap gelê. Daar was geen sprake daarvan dat die kerklike organisasie 'n voortsetting van die kerk in die Kolonie was nie. Dit was al, vanweë die Herderlijke Brief van 1837, onmoontlik en tweedens was Erasmus Smit nog 'n predikant nòg 'n lidmaat van die Kaapse kerk.

Hoewel enkele van dié eerste kerkraadslede in die Voortrekkerkerk ók in die Kolonie kerklike ampte beklee het, het dit nie beteken dat die eerste Voortrekkergemeente 'n voortsetting van die kerk in die Kolonie was nie. Inteendeel, die indruk wat Erasmus Smit in sy Dagboek skep is dat hier 'n nuwe begin met 'n selfstandige kerklike organisasie gemaak is. Buitendien het die Voortrekkers voortdurend geargumenteer dat hulle by hulle vertrek uit die Kolonie hulle Britse burgerskap agtergelaat het. Dit het die kerk dár ook gegeld wat nie net binne die grense van die Kolonie vasgepen was nie, maar wat ook so min of meer as staatskerk van die Kolonie gefunksioneer het.

Die selfstandigheid van die Voortrekkerkerk word ook bevestig deur 'n tydgenootlike berig wat stel (Chase 1968 I: 87): '(Mr Retief) is busily engaged in framing regulations for establishing and supporting public worship according to the system of their forefathers, viz; The Dutch Reformed Church'. Hoewel onafhanklik van die Kaapse kerk is dit wél duidelik dat Retief en die Voortrekkers hulle eie kerk so wil inrig dat dit ooreenkom met die kerk in die Kolonie. Dit gaan dus om organisatoriese selfstandigheid, maar nie om 'n leerstellig bepaalde afskeiding nie (vgl ook Chase 1968 I: 90). Die selfstandigheid van die Voortrekkerkerk word ook deur latere gebeure beklemtoon wanneer Erasmus Smit in 1841 deur die Volksraad geëmeriteer word en in sy plek die Amerikaanse sendeling onder die Zoeloes, Daniel Lindley, aangestel word (De Jongh 1977: 172-173). Opvallend is dat die Volksraad, wat hier ook volgens die ius patronatus opgetree het, aan Smit verkorte 
emeritaats-regte verleen het deur hom te verbied om verder die sakramente te bedien. Lindley het as predikant in die Voortrekkerkerk die gemeentes Pietermaritzburg, Weenen en Port Natal en wes van die Drakensberge die gemeentes Winburg en Potchefstroom bedien. Al dié gemeentes is deur besluite van die Volksraad in die lewe geroep en dit dui onteenseglik daarop dat die Voortrekkerkerk 'n selfstandige en eie organisasie in die Voortrekkerrepubliek was wat geen organisatoriese bande met die kerk in die Kaapkolonie gehad het nie. Terselfdertyd dui dit ook op 'n duidelik bepaalde siening van die volk en die gemeenskap waardeur die kerk funksioneer as die kerklike keersy van die burgerlike maatskappy. Omdat die Voortrekkers as gedoopte gemeenskap hulleself as 'n verbondsvolk beskou het, was hulle siening van die koppeling kerk en volk byna vanselfsprekend en ook in lyn met die opvattings wat hulle by á Brakel gekry het (Pont 1986).

Die organisatoriese bande met die Kaapse kerk ontstaan eers nadat Natal in 1843 en die Oranjeriviergebied in 1848 deur die opdringende Engelse imperialisme geannekseer is. Dán is daar skielik wél predikante van die Kaapse kerk beskikbaar wat sowel in Natal as in die Vrystaatse gebied deur die Engelse goewerneur in die nuwe kolonies aangestel kan word (Spoelstra 1963: 105-106). As die imperiale vlag oor Natal en die Oranjeriviersoewereiniteit waai, dan word die Afrikaanssprekende 'staatskerk' van die Kolonie deur owerheidsproklamasies uitgebrei met die oorblyfsels van die Voortrekkergemeentes. Maar dan is dit 'n kerklike 'anneksasie' wat parallel loop met die politieke anneksasie van die Gelofteland en die Vrystaatse gebied (Storm 1984: 127-128).

\section{DIE SOEKE NA 'N PREDIKANT}

Hoewel Erasmus Smit in 1837 deur Goewerneur Retief as die eerste predikant van die selfstandige Voortrekkergemeenskap aangestel word, was dit ook so dat hy nie algemeen so deur al die Voortrekkers aanvaar is nie. Dit het nie beteken dat die selfstandigheid van die Voortrekkerkerk bevraagteken is nie, maar wel dat Smit se bevoegdheid om predikant te wees, onder ' $n$ vraagteken geplaas is. Tog het Retief nog op 9 September 1837 in 'n skrywe aan die Goewerneur van die Kolonie gestel (Chase 1968 I: 110):

Our religious services are by no means neglected, but on the contrary earnestly and constantly conducted according to the established forms and practices of the Dutch Reformed Church. We have, thank God, a truly good Divine amongst us, whom we acknowledge as a faithful shepherd to his flock. 
Maar dit was ook so dat in Maritz se laer dit gewoonlik Sarel Cilliers was wat die dienste gehou het en dat Erasmus Smit dár nie aanvaarbaar was nie. Om 'n goedopgeleide predikant te kry, het die Voortrekkers allereers getrag om 'n predikant uit die Kaapse kerk te kry en daarna is die oë na Nederland gewend.

Uiteindelik moes hulle met die Amerikaanse Presbiteriaan, Daniel Lindley, tevrede wees wat na die oordeel van Susanna Smit openlijk onder den naam van gereformeerde den Leer van Weslij predikte (De Jongh 1977: 182). Dit is opvallend dat die Voortrekkers by hulle navrae na 'n predikant, iemand gesoek het wat sou aansluit by hulle bevindelik-ortodokse opvattings, 'n rigting wat hulle wél by Erasmus Smit gevind het (Steenkamp 1920: 35). As egter gelet word op die manier waarop hulle te werk gaan, ontstaan die vraag of die teologiese rigting van die predikant inderdaad belangrik was.

Die soeke na ' $n$ predikant deur die Voortrekkers is die verhaal van baie pogings wat misluk het. Alreeds met die uittog uit die Kolonie is pogings aangewend om 'n predikant te vind om die tog saam met die Trekkers aan te pak. Die mees bekende poging was dié van Piet Uys wat 'angsvallig' na so 'n predikant gesoek het. Slegs Erasmus Smit, die sendeling, was toe bereid om saam te gaan. Smit was skaars as predikant aangewys of hy moes op 19 Mei 1837 verneem dat die Maritz-laer 'n tweede predikant wil beroep (De Jongh 1977: 131). Dit lei daartoe dat Retief en Maritz in Junie 1837 vir Frans Schultz, 'n Kaapse handelaar wat by die Voortrekkers vertoef het, vra om aansoek te doen, naar een goeden en bekwamen Gereformeerden Leeraar (Dreyer 1929: 11-12).

'n Tweede poging was 'n skrywe aan kmdt-genl AWJ Pretorius in Junie 1838 aan ds GWA van Lingen waarin hy die predikant se hulp vra om een goede Leeraar vir die Voortrekkers te bekom (Dreyer 1929: 12-13). Die poging word opgevolg deur 'n skrywe van die Representanten van den Trekraad in Mei 1839 aan die vier Kaapse predikante A Faure, T Herold, GWA van der Lingen en PE Faure. Dár vra hulle dat dié predikant moet een man weezen die hem vasthoudt aan de zuivere oud Hollandsche gerevormeerde Godsdienst (Dreyer 1929: 15), een waare Voonganger van den Godsdienst onzer Vaderen (Dreyer 1929: 16).

As dié poging niks oplewer nie, gaan die Volksraad op 7 Maart 1840 daartoe oor om ds PK Albertyn te beroep (Preller 1924: 42). Nadat dié poging misluk, het die Kerkraad van Pietermaritzburg 'n skrywe aan Jacob Swart in Nederland, wat 'n handelskip na Natal gestuur het, gerig. Dié poging lei daartoe dat 'n komitee in Nederland prop PN Ham bereid vind om na Natal te gaan. Maar Ham bereik nooit die Voortrekkers nie, want as sy skip in Port Natal aankom, is die land so pas deur Engeland geannekseer en word Ham nie toegelaat om aan wal te gaan nie (Storm 1984: 97-98). 


\section{NA DIE ANNEKSASIES VAN NATAL EN DIE VRYSTAAT}

Nadat Natal in 1843 en die Vrystaatse gebied in 1848 geannekseer is, het net die Oorvaalse deel van die Voortrekkerpubliek oorgebly, dié deel wat deur Hendrik Potgieter se suksesse teen die Matabeles oopgestel is vir blanke bewoning. Kerklik gesproke het dit beteken dat van die Voortrekkerkerk nét die gemeente Potchefstroom oorgebly het, 'n gemeente wat aanvanklik al die inwoners noord van die Vaalrivier omvat het.

'n Merkwaardige faset van die Kaapse kerk se bemoeienis met die Voortrekkergemeentes blyk uit Dr Wm Robertson se aanbevelings aan die Goewerneur, sir Harry Smith, nadat hy as lid van die tweede deputasie na die Kaap teruggekeer het. Nadat hy die Goewerneur bedank het dat hy ds Andrew Murray jr as predikant te Bloemfontein aangestel het, skryf hy (Gerdener 1930: 101) : ' $\ldots$ and I trust that he (d i ds Murray) will be able at least once a year, to visit the countries beyond the Vaal River, whose Inhabitants will, I trust, - by such appointments in the Sovereignty, soon feel convinced of the superior advantages enjoyed by those who live under a regular Government'.

Dit was duidelik dat Robertson, wat die Goewerneur in ander skrywes oor politieke sake sou inlig, inderdaad gedink het dat die Kaapse kerk 'n belangrike rol moes speel om die Engelse bewind vir die Voortrekkers aanvaarbaar te maak. Hierin het Robertson die gedagtes van sir Harry Smith self gevolg (Gerdener 1930: 92).

Hierdie tendens in die optrede van die Kaapse predikante is veral deur kmdtgenl Andries Pretorius raakgesien en daarom was hy skerp gekant teen Kaapse predikante in die Voortrekkerkerk (Storm 1984: 143).

Maar aan die ander kant was daar ook 'n gedagterigting in die Oorvaalse wat van mening was dat nouer skakeling met die Kaapse kerk dalk tóg 'n predikant vir Transvaal sal oplewer (Dreyer 1929: 146).

Inmiddels was die Voortrekkers in die Oorvaalse aangewese op die periodieke besoeke van ds Andrew Murray vanuit Bloemfontein. Dié bediening van Murray het met die instemming van die imperiale owerhede geskied omdat geoordeel is dat hy 'n groot bydrae lewer tot die sekuriteit van die Vaalriviergrens vanweë sy matigende invloed op die Trekkers (Gerdener 1930: 109).

Inmiddels het die Volksraad, soos nodig, nóg gemeentes in die Oorvaalse gestig omdat die wyke van Potchefstroom, naamlik Ohrigstad, Magaliesberg en Zoutpansberg tot selfstandige gemeentes ontplooi het. So kom die gemeentes Lydenburg in 1849, Rustenburg in 1850 en Zoutpansberg in 1852 tot stand (Storm 1984: 147-148). Dié ontwikkeling en organiese groei is ook deur Murray se reëlmatige besoeke gestimuleer en het hy in 'n breë kring die agting van die lidmate verdien. Dit bring 
mee dat hy na Rustenburg beroep is, maar hy het dié beroep nie aangeneem nie (Storm 1984: 152). So ontstaan 'n merkwaardige situasie: Enersyds bestaan daar by die lidmate en volksleiers ' $n$ vrees dat te noue betrekkinge met die Kaapse kerk kan lei tot anneksasie deur Engeland. Andersyds het die behoefte aan reëlmatige kerklike bediening die lidmate en volksleiers weer gedwing om telkemale die Kaapse kerk vir hulp te nader. Dit veral omdat die poging in 1849 onderneem om 'n predikant uit Nederland te kry, misluk het (Storm 1984: 146). Geleidelik word dit nou duidelik dat vir die Transvaalse gemeentes die verkryging van 'n eie predikant, hulle hoogste prioriteit is. Daarteenoor wou die Kaapse predikante, soos Murray, ters die Transvaalse gemeentes in die Kaapse kerklike organisasie laat opgaan voordat 'n predikant na Transvaal kon kom. Die verskil in opvatting kom in 1851 duidelik na vore as Murray en sy broer John 'n poging aanwend om die Transvaalse gemeentes by die Ring van Transgariep, wat die Natalse en Vrystaatse gemeentes saamgesnoer het, in te skakel. Sowel Potchefstroom as Rustenburg het die voorstel vanweë politieke zaken nié aangeneem nie (Engelbrecht 1955: 65-66). Dit bly buitendien vreemd dat die beide Murrays geoordeel het dat dit moontlik was om gemeentes wat buite die Engelse gesagskring gestaan het, in die 'staatskerk' van die Engelse kolonie in te lyf. Die poging in 1851 om die Transvaalse gemeentes in die kerklike organisasie van die Kaapkolonie in te skakel word afgewys, omdat dit vir die Voortrekkers nie 'n prioriteit was nie; die verkryging van 'n predikant wel.

Die staatkundige situasie word dramaties verander wanneer in Januarie 1852, vanweë die deurtastende optrede van kmdt-genl Andries Pretorius, die onafhanklikheid van die gebied noord van die Vaalrivier deur Engeland, met die ondertekening van die Sandrivierkonvensie, erken en aanvaar word.

Die implikasies van die erkenning was nog nie behoorlik deurgedink nie, so wil dit voorkom, wanneer Andrew Murray en ds JH Neethling in 1852 weer in die Oorvaalse aankom met ' $n$ aanbod van 'n predikant indien die gemeentes èn die Volksraad inlywing by die Kaapse kerk sou aanvaar. Dié aanbod is so aanvaar en ook deur die sinode van die Kaapse kerk in Oktober 1852 bekragtig, hoewel die voorwaardes enigsins gewysig is (Pont 1987: 241). Voordat daar egter iets van gekom het, het 'n verdere gebeure die gang van sake in 'n ander loop gestuur. Dit was enersyds die koms van ds Van der Hoff wat in Mei 1853 in Potchefstroom aangekom het en andersyds dat dit bekend geword het dat Andrew Murray by Sandrivier die onafhanklikheidserkenning deur Engeland teengestaan het en daarna ook standpunt ingeneem het teen onafhanklikheid vir die Vrystaat (Spoelstra 1963: 108). Dit het in die Transvaalse gemeentes onmiddellik die vrees vir Engelse inmenging in die Republiek deur middel van die kerk, opnuut laat opvlam. 
Die uiteinde was dat die eerste Algemene Kerkvergadering van die Transvaalse gemeentes die inlywing verwerp het en gestel het: ... burgerlijk vij en onafhankelijk, wenschen wij dit ook in het kerkelijke. Daarmee het die Algemene Kerkvergadering die onafhanklikheid van die Voortrekkerkerk herbevestig en gehandhaaf. Ten opsigte van die verhouding met die Kaapse kerk het die Algemene Kerkvergadering aan dr Abraham Faure geskryf (Gerdener 1930: 584):

De Nederduitsch Gereformeerde Kerk in de Zuid-Afrikaansche Republiek, beschouwd zich derhalve als een onafhankelijke kerk, onder haar eigen bestuur.

Hiermede wordt echter niet te kennen gegeven, dat zij zich afsnijdt of afscheurt van hare oude Moeder kerk. In geenen deele. De dochter wil nog gaarne met hare moeder in kinderlijke betrekking blijven; met andere woorden: de Nederduitsch Gereformeerde Kerk in deze gewesten wenscht, ofschoon onafhankelijk, een band van vereeniging aan te knoopen, ten doel hebbende de algemeene belangen der Nederduitsch Gereformeerden in Zuid-Afrika te behartigen, en wederzijds elkander die broederlijke diensten te bewijzen, die het Evangelie zijnen belijders voorschrijft of beveelt. Om dat doel te bereiken, ... wenschen wij hartelijk in een geregelde briefwisseling met elkander te komen, ....

Ten slotte is bepaal dat die bestaande Transvaalse gemeentes die enigste kerk in die nuwe Republiek sou wees (Gerdener 1930: 576).

So is die onafhanklikheid van die Voortrekkerkerk, waarvan die grondslae in 1837 gele is, in 1853 o6k beklemtoon en gehandhaaf nadat die Voortrekkerideaal van 'n eie, onafhanklike vaderiand in Januarie 1852 by Sandrivier 'n werklikheid geword het.

\section{SLOTOPMERKINGS}

Samevattend kan gestel word dat die geskiedenis van die Voortrekkerkerk in die jare 1837-1852 net so ' $n$ interessante geskiedenis was as die pogings van die Voortrekkers om 'n onafhanklike republiek te vestig. Daarby word dit reeds in hierdie jare duidelik dat daar ook 'n duidelike verskil in opvatting van die plek van die kerk in die samelewingstruktuur van die Voortrekkers was. Hoewel die gegewens om tot sluitende gevolgtrekkings te kom ontbreek, wil dit tog voorkom dat agter die Sarel Cilliers-Erasmus Smit botsing, mér sit as net 'n botsing van persoonlikhede. Uit sy Dagboek en uit die verloop van sake is dit duidelik dat 
Erasmus Smit 'n voorstander van die Calvinistiese teokratiese ideaal en sodoende van 'n nasionale staatskerk was. Vir dié opvatting het hy veral steun gevind by á Brakel.

Sarel Cilliers wat veral sy staanplek in die Maritzlaer gehad het, was waarskynlik meer geneë om die vrye kerk gedagtes te steun. Dit kan dalk blyk uit die feit dat Maritz waarskynlik die mees Patriot-gesinde Voortrekkerleier was en dus 'n sterker waardering vir die demokratiese siening gehad het. Die feit dat sy volgelinge hulle merendeel aansluit by JJ Burger met sy oordrewe demokratiese opvattings, wys $66 \mathrm{k}$ in daardie rigting. Dit is ook ' $\mathrm{n}$ vraag of Cilliers se steun van Lindley teenoor Erasmus Smit nie ook in daardie rigting wys nie. So kan die wortels gesoek word van die latere kerklike verdeeldhede in die Oorvaalse wanneer die Lydenburgse regionaal-politieke groep hom losmaak van die Wes-Transvaalse regionaalpolitieke groep wat die teokratiese visie gehandhaaf het en die Voortrekkerkerk in 1857 die staatskerk van die ou Zuid-Afrikaansche Republiek gemaak het.

Dit is ook duidelik dat die posisie van die Kaapse kerk in die kolonie, die Herderlijke Brief van 1837 en die politieke standpunte wat die Kaapse predikante ingeneem het, van die begin af beteken dat die Voortrekkers 'n eie organisatories selfstandige kerk georganiseer het. Inhoudelik het hulle vasgehou aan die geërfde kerklike gebruike terwyl hulle teologies hulle bevindelik-ortodokse Calvinistiese opvattings gehandhaaf het. Daarom wou die Voortrekkers nooit die geloofsverbintenis, die eenheid op die geloofsvlak, met die Kaapse kerk verbreek nie. Politieke verwikkelinge het die kerklike ontwikkeling in die Oorvaalse nog lank na 1852 bepaal en die wanbegrip wat daar by die Kaapse kerk was vir die kerklike opvattings in die Oorvaalse het aan die verloop van die kerkgeskiedenis sy eiesoortige kinkels gegee.

Om gebeure na 1852 na waarde te kan skat bly dit belangrik om te let op die plek, die struktuur en die inhoud van die Voortrekkerkerk in die Voortrekkergemeenskap. Hoewel dit maar kerk in 'n eenvoudige vorm was, was daar tóg 'n geestelike tuiste vir die gelowiges wat alles feil gehad het vir hulle ideaal om ' $n$ vrye, onafhanklike vaderland in Suidelike Afrika te soek en te vind.

\section{Literatuurverwysings}

á BRAKEL, W 1736. Redelijke godtsdienst. Rotterdam: Wed H van den Aak.

CANISIUS, A 1986. Veritas: Herinneringen van 1861-1902. Krugersdorp:

Dolphinpers.

CHASE, JC 1968. The Natal Papers. Facsimile reprint. Cape Town: C Struik.

DE JONGH, PS 1977. Die lewe van Erasmus Smit. Pretoria: HAUM. 
DE JONGH, PS 1981. Sarel Cilliers en die oorsake van die Groot Trek: 'n Herwaardering. Tydsknif vir Geesteswetenskappe 21/3.

DE KLERK, LC 1918. Herinneringe, in Preller GS, Voortrekkermense, Deel 1. Kaapstad: De Nationale Pers.

DREYER, A 1929. Die Kaapse kerk en die Groot Trek. Kaapstad: Van Sandt, De Villiers \& Co.

DREYER, A 1936. Boustowwe vir die geskiedenis van die Nederduits-Gereformeende kerke in Suid-Afrika. Kaapstad: Nasionale Pers.

DUVENAGE, GDJ 1986. Die Groot Trek: Die eerste drie jaar, Deel 1: 1836 Vegkop. Pretoria: Die Afrikanervolkswag.

DUVENAGE, GDJ 1986. Die Groot Trek: Die eerste drie jaar, Deel 2: 1837. Die manifes. Pretoria: Die Afrikanervolkswag.

DU PLESSIS, CNJ 1898. Uit de geschiedenis van de Zuid-Afrikaansche Republiek en van de Afrikaanders. Kaapstad: JH de Bussy.

DU TOIT, HDA 1972. Vos, Michiel Christiaan, in De Kock WJ \& DW Krüger, Suid-Afrikaanse Biografiese Woordeboek, Deel II. Kaapstad: Tafelberg.

ENGELBRECHT, SP 1955. Geskiedenis van die Nedenduitsch Hervormde Kerk van Afrika. Kaapstad: Haum.

GERDENER, GBA 1930. Boustowwe vir die geskiedenis van die Nederduits-Gereformeerde Kerk in die Transgariep. Kaapstad: Nasionale Pers.

GERDENER, GBA 1934. Ons kerk in die Transgariep. Kaapstad: Nasionale Pers.

GORDON MEARS, W 1973. Methodism in the Cape: An outline. Cape Town: Methodist Publishing House.

GRAAFLAND, C 1986. Kernen en contouren van die Nadere Reformatie, in Brienen, $T$ et al, De Nadere Reformatie. Den Haag: Boekencentrum NV.

HANEKOM, TN 1959. Helperus Ritzema van Lier: Die lewensbeeld van 'n Kaapse predikant uit die 18de eeu. Kaapstad: NG Kerk-Uitgewers.

KLEYNHANS, EPJ 1973. Die kerkregtelike ontwikkeling van die Nederduitse Gereformeerde Kerk in Suid-Afrika 1795-1962. Ongepubliseerde DD-proefskrif, Universiteit van Stellenbosch.

MALAN, CJ 1981. Die Nadere Reformasie. Potchefstroom: Potchefstroomse Universiteit vir CHO.

PONT, AD 1978. Die Herderlijken Brief van die sinode van 1837. HTS 34/4.

PONT, AD 1986. Verbond en Volkskerk. HTS 42/1.

PONT, AD 1986. Die Voortrekkerkerk 1836-1852. Ongepubliseerde lesingaantekeninge, Universiteit van Pretoria.

PONT, AD 1988. Die sekerheid van die geloof by Calvyn en sommige van sy navolgers. HTS 44/2. 
PRETORIUS, HS \& KRüGER, DW 1937. Voortrekker Argiefstukke 1829-1849. Pretoria: Die Staatsdrukker.

PRELLER, GS 1924. Voontrekker Wetgewing: Notule van die Natalse Volksraad 1839-1845. Pretoria: Van Schaik Bpk.

QUIGLEY, C 1974. Tragedy and hope. Los Angeles: WM Morrison.

SCHOON, HF 1897. Uit het dagboek van Erasmus Smit, predikant bij de Voortrekkers. Kaapstad: Townsend, Taylor \& Schashall.

SPOELSTRA, B 1963. Die Doppers in Suid-Afrika 1760-1899. Kaapstad: Nasionale Boekhandel.

STORM, JMG 1984. Die Voortrekkerkerk. Ongepubliseerde DD-proefskrif, Universiteit van Pretoria.

STEENKAMP, A 1920. Gedenkskrif, in Preller GS, Voortrekkermense, Deel II. Kaapstad: Nasionale Pers.

VAN DER WATT, PB 1973. Die Loedolff-saak en die Nederduitse Gereformeerde Kerk 1862-1962. Kaapstad: Tafelberg-Uitgewers.

VAN JAARSVELD, FA 1974. Geskiedkandige Verkenninge. Pretoria: Van Schaik.

VAN GENDEREN, J 1986. Wilhelmus á Brakel 1635-1711, in Brienen, T et al, Die Nadere Reformatie: Beschrijving van haar voormaamste ventegenwoordigers. Den Haag: Boekencentrum NV.

VAN 'T SPIJKER, W 1986. Die Nadere Reformatie, in Brienen, T et al, De Nadere Reformatie: Beschrijving van haar voomaamste vertegenwoordigers. Den Haag: Boekencentrum NV. 